\title{
THE EFFECT OF INTRINSIC AND EXTRINSIC MOTIVATION ON CIVIL SERVANTS' PERFORMANCE
}

\author{
Elvira NICA ${ }^{a}$, Ana-Mădălina POTCOVARU ${ }^{b^{*}, \text { Ioana PADURARIU }}$ \\ a,b,cBucharest University of Economic Studies, Romania
}

\begin{abstract}
Over the past two decades, research on public service motivation and civil servants' performance has been developed continuously. This article examines the key aspects of the literature on public service motivation and performance of the public sector. Research on this subject shows that public service motivation has a great impact on individual and organizational performance.

The literature provides a lot of examples in which the quality of human resources management influences organizational performance. The key aspects of the literature on public service motivation are referring to: political motivation, public interest and social responsibility, civic duty, social justice,, social compassion, and self-sacrifice (Hammerschmid et al., 2009). The aim of the article is to examine the factors that influence civil servants' performance.

This article analyses differences between intrinsic and extrinsic incentives to suggest management implications directed to support motivation and performance of employees in public organizations.
\end{abstract}

KEYWORDS: civil servants, human resources, motivational system, performance, public sector

DOI: $10.24818 / \mathrm{IMC} / 2021 / 04.10$

\section{INTRODUCTION}

Motivation is a central driver of success for any organization, acts as a predictor of individuals' behavior and performance and contributes to organizational performance. Motivation alone is not enough to explain performance and especially organizational performance (Ritz et al., 2016, p. 3). Behavior may be understood as a function of motivation, ability, and situational factors such as resources and interpersonal support (McClelland, 1985). Motivation in the public sector is strongly connected to institutional setting and parts which define the structure of institutions - values, norms, and rules (Peters 2000; Selznick 1984; Ritz et al., 2016). Employees' values are influenced by the organizational 'publicness' (Ritz \& al, 2016 p.7). The attitudes of employees have an immense effect on their conducts in the workplace (Lăzăroiu, 2015, p. 66)

The main purpose of this study is to provide an overview of the incomes and outcomes of civil servants and to investigate the relationship between having a higher level of commitment and high levels of public service motivation among employees of the public administration. Also, the persistence of his behavior is important for the individual and organizational goals. One of the main reasons to study public service motivation (PSM) is to reveal the extent to which it influences in individual behavior and to what extent it can improve the performance of organization. The importance of pay related system is seen in this article in the case of France and Germany. The value and goal congruence are the keys to understanding the nature of public employees' motivation (Wright \& Pandey, 2008).

\footnotetext{
*Corresponding author. E-mail address: ana.potcovaru@amp.ase.ro
} 


\section{MOTIVATION IN THE PUBLIC SECTOR}

A considerable amount of literature has been published on employee motivation in the public sector, but studies fail to consider the link between motivational needs and the dialogue feedback between managers and employees about increasing performance.

Public service motivation represents the form of employee motivation specific to the public sector (Ciobanu et al., 2019)

The degree of motivation of an employee in a public authority is based on the analysis of work needs and both intrinsic and extrinsic motivational factors. The notion of performance is specific to private sector and when it comes to the public sector the definition of objectives and results indicators is more complex. Public employees' performance at the workplace is influenced by intrinsic motivational factors, such as responsibility, autonomy, interesting and important work, contribution, or fairness (Ciobanu \& Androniceanu, 2015; Piatak, 2016; Ciobanu et al., 2019).

Public Service Motivation (PSM) involves understanding and explaining employees' public beliefs and this article sets out to describe the attitudes generated by these beliefs, it makes sense to think about cultural distinction between administrative offices in which this measure is approached.

In this sense, the PSM captures the measure in which the public employee activates- specific to the traditional model. And in the opposite direction, the trend towards management and privatization contributes to transforming senior public officials into managers and managers progressively replacing their identity as "public servants" (civil servants).It should be clear that a manager is not just an acting subject to the staff and can influence their performance, motivation positively or negatively through management action, brings motives and values to the workplace but also as employee's needs.

Many authors conclude that the influence of the PSM on the choice of the sector for starting a career and staying in this sector is influenced by the perception of the work conditions, organizational command structure, incentives/rewards and personal empowerments that may improve or diminish motivation in order to contribute to a higher productivity

\subsection{Methodology}

This article is an empirical study regarding public sector motivation, based on the main theories of motivation. The intrinsic and extrinsic motivation are analyzed and also are presented theoretical aspects regarding performance-related pay (PRP) and work motivation from the French civil service and German public administration.

The purpose of this article is to analyse the actions and procedures needed to implement to motivate public employees and to contribute with solutions and recommendation to achieve established output goals. The main research questions are what actions are needed in order to motivate employees and what is the relation between work needs and motivational factors, both intrinsic and extrinsic, with the degree of motivation of a public employee. Also, it is important to analyze the link between performance rewards to individual achievement of public value.

This article is based on different reports from OECD, EUPAN, European Commission and a great number of articles regarding the main concepts of this study: motivation, public service motivation, intrinsic and extrinsic rewards, pay related system.

\subsection{Theories of motivation}

In recent years, there has been an increasing number of suggestions for grouping the approaches. In the application-oriented literature, a distinction is often made between content and process theories as two basic types. Content theories of motivation provide stable needs and motives inherent in the person and values come to the fore. Process theories focus on offering something in exchange for some. 
Abraham A. Maslow's hierarchy of needs was particularly influential in the application-oriented literature for executives. According to this strand of theory, the behavior of the person is explainable by the fact that it aimed at achieving a specific objective in terms of content, in particular the satisfaction of a need. According to the version, there is a hierarchy of needs that starting from the basic physiological needs, increasing over several levels and culminates in the need for selfrealization.

In management literature the analytical framework for intrinsic motivation is the expectancy theory of Vroom (1964), which explains the link between motivation and performance viewed as a rational choice. (Forest, 2014, p.328). First of all, the individual must believe that he is able to perform at the desired level. This part is known as effort-performance-expectancy (Forest 2014; Roussel, 1996). The performance outcome expectancy is important in the second part, which means that the individual must be sure that his performance will conduct to outcomes and in the third part the outcomes must be attractive for the individual. (Forest, 2014, p.328).

\subsection{Extrinsic and intrinsic motivation}

Some of the studies found that extrinsic rewards increased intrinsic motivation (Cameron 2001; Greener 2019; Wenzel, Krause and Vogel, 2019). Some authors explained that the types of extrinsic motivation have different degrees of intrinsic elements and these factors increase employee work effort and job satisfaction. The initial distinction made in the dichotomy between intrinsic and extrinsic motivation was referring to the absence or presence of external rewards (Lee, 2021, p.92).

The extrinsic motivation is based on extrinsic financial motivation - earning always more money and intrinsic incentives identified by researchers and practitioners are the following: job security, good compatibility of work and private life, an interesting occupation, relative autonomy at work. Extrinsic motivation is referring to "rewards", which are variable financial bonuses, benefits, addson, stock options in addition to the fixed base pay of an employee. A "reward" is a sum in addition to the monthly salary which can be awarded for various reasons, e.g. for good performance, for managerial tasks, etc. (EUPAN, 2016, p. 45). Public officials can be rewarded in different ways, ways at least as important as the high salaries which are more subtle and less direct (Brans \& Peters, 2012).

Table 1. Matrix of rewards for high public officials

\begin{tabular}{|l|l|l|}
\hline \multirow{2}{*}{ Tangibility } & \multicolumn{2}{|c|}{ Formality } \\
\hline \multirow{4}{*}{ Tangible } & Formal & Informal \\
\cline { 2 - 3 } & $\begin{array}{l}\text { - Base pay, } \\
\text { - Formalized performance related } \\
\text { bonuses } \\
\text { - Collective pension system, retirement } \\
\text { benefits, } \\
\text { - "Professional development }\end{array}$ & $\begin{array}{l}\text { - Small or bigger presents, } \\
\text { - Privileges (official residences) } \\
\text { - "Study trips" abroad, } \\
\text {-Well-paid post-government employment }\end{array}$ \\
\hline & $\begin{array}{l}\text { - Medals, } \\
\text { - Ribbons, } \\
\text { - Awards, } \\
\text { - Titles (nobility in UK, Belgium, Spain) }\end{array}$ & $\begin{array}{l}\text { - Positive prestige due to respect and social } \\
\text { esteem, } \\
\text { - Negative prestige due to the fear you } \\
\text { inspire to others, } \\
\text { - Self-esteem }\end{array}$ \\
\hline
\end{tabular}

Source: adapted from Hood et al. (1994, pp. 8-10)

The tangible rewards are more concrete and have various forms. Intangible rewards are those that have no immediate money value. In this category is included the satisfaction of believing oneself to 
be working for the common good of society (Hood et al 1994, p. 8). Many tangible rewards can be informal, as it can be seen from table 1 .

\subsection{Public Service Motivation (PSM)}

The "management by rewards" issue for the Civil Service is one key feature inherited from the New Public Management. At the beginning of the ' 90 s, public service motivation originated in the USA, as a countermovement to the reforms in the spirit of New Public Management, whose main reason was to transfer business models to the administration. (Pollit \& Bouckert, 2004). A representative concept of the public service motivation is that employees of the public service have a particularly strong focus on the common good. "Public service' is an attitude, a sense of duty" (Staats, 1988). The idea that public employees get through should mark a special obligation for the common good.

Grant (2008) notes that intrinsic motivation is joy and pleasure, prosocial motivation (and also PSM) emphasizes the meaning and purpose as the cause of exertion. There are different opinions regarding whether public service motivation is an intrinsic form of motivation or not. Some authors considered that PSM could be conceptualized as the personal orientation toward the contribution to the noble public goods (Lee, 2021, p.105). In other author opinions, public service motivation is different from intrinsic motivation. For example, Houston considered that PSM is more broadly than the tendency of valuing non-monetary rewards. (Houston, 2000). Other authors define Public Service Motivation as the desire to behave in accordance with motives that are grounded in the public interest in order to serve society (Ritz \& al, 2016).

Perry created Six Dimensions of Public Service Motivation (Perry 1996). In his research for each dimension Likert - type items were developed to create the PSM scale. The six dimensions are presented in figure 1.

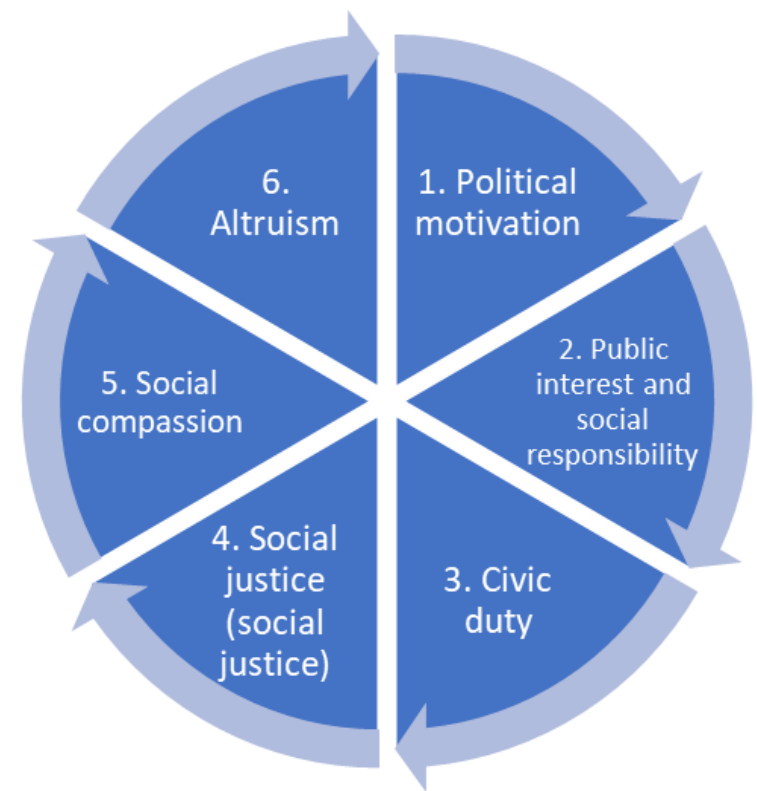

Figure 1. The Six Dimensions of Public Service Motivation Source: adapted from Perry (1996)

Figure 1 shows that that the six dimensions are: political motivation (affinity to public policy), public interest and social responsibility (commitment, devotion, dedication to the public interest, attraction to public policy), civic duty (commitment to the public interest), social justice (social justice), social compassion (compassion), and altruism (self-sacrifice) (Hammerschmid et al., 2009; Perry 1996). These dimensions and their associated items became the standard instrument in PSM research and 
formed the basis for many further studies. This concept found widespread acceptance in public management research.

Assumption that Perry and Wise (1990) made about the implications of public service motivation, aimed at the use of motivational incentives.

Apart from the structure, there are many other aspects of public service motivation, which have been investigated since the concept was established (Syamsir, 2016).

Among the most important is the question of whether the PSM is a dependent or is an independent variable: that means whether the public employees work in the public service because they have a high PSM or they have a high PSM because they are employed in the public sector.

In recent years, however, there have been various criticisms that the Public Service Motivation is only viewed in isolation and not within the broad scope of the psychological process theories of motivation (Wright, 2007, p. 54).

The public service motivation is not incompatible with the performance management. The practice of performance pay will contribute to the degree of recognition of the employees for which the public values are important, and they have a contribution in achieving public goals and values. (Steijin, 2008)

Public service motivation theory shows that the forms of non-monetary rewards are more important for some civil servants than financial rewards such as performance-related pay (Forest, 2008, p. 336)

\subsection{Public service motivation, satisfaction and pay related performance}

Motivation and performance have been central questions in psychological, business, and sociological literature.

PSM is considered a construct with homogeneous properties and wide applicability, in European and Asian countries (Perry, 1996). The concerns are that the dimensions of the PSM have a distinct meaning in a cultural environment much different from American one (Riba \& Ballart, 2007).

The focus was always on whether there are motives (in the sense of motivational bases) that are primarily or exclusively connected with the public service and if so, which motives are these (Perry \& Wise, 1990).

There were researchers, even in the early days of administrative science, who advocated it interested in what motivates public sector employees.

The PSM research does not assume that Public Service Motivation can only be found in the public sector, but that the PSM is based on the tasks of the public service and is found more strongly in the public sector than in other sectors (Rainey \& Steinbauer 1999; Wise 2000).

The six factors that affect the performance alignment according to Nickols (2016) are: commitment, competence, cooperation, connections, clarity, circumstances. Depending on the existing organization culture, the need to belong can have a performance-enhancing or inhibiting effect.

Perry and Wise, in their article, assumed that people with a high public service motivation often choose and remain in the public service (Perry \& Wise 1990). 
The categories of motivations are the following:

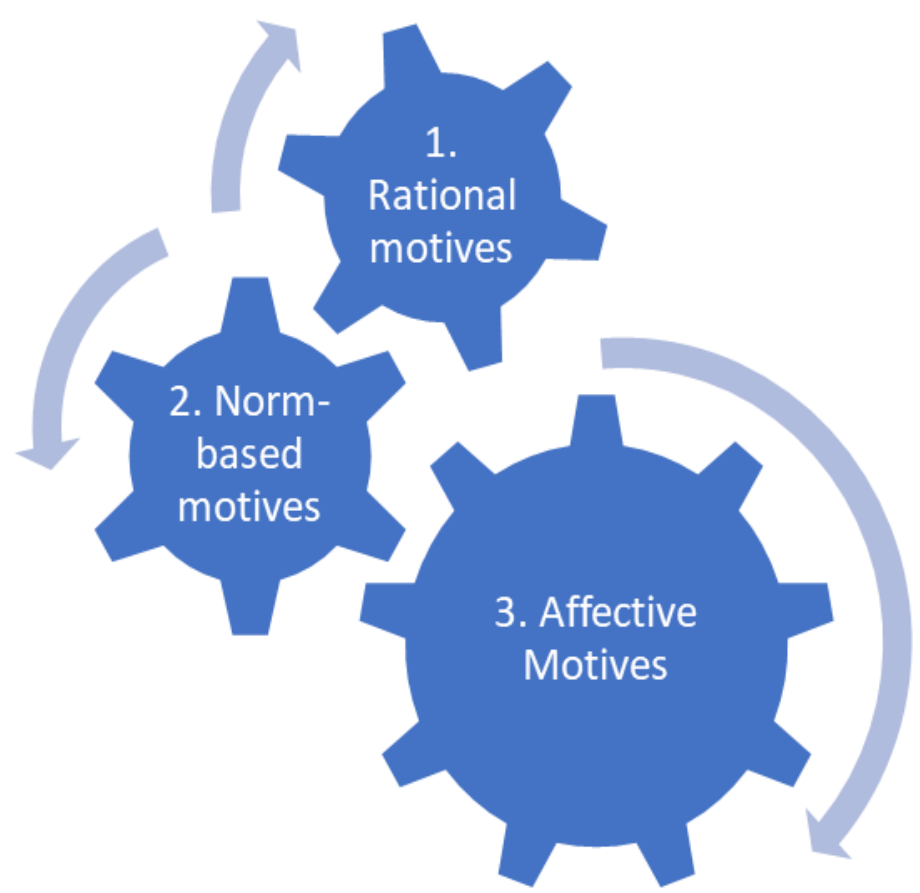

Figure 1. Categories of motivations that can be found in the public sector Source: adapted from Perry and Wise (1990)

Rational motives refer to an individual who is interested in a certain public service because it identifies with its targets/ambitions/objectives; reasons normative - when a person believes in the public interest, including even a communal belief and loyalty towards government institutions; and affective motives characterized by the desire to help other people. (Riba, Ballart, 2007)

In this scheme, rational motives include actions based on individual preferences and maximizing benefits. Norm-based motives refer to actions taken to conform to norms.

They further postulated a positive connection between public service motivation and performance in the public service.

Several entities are notably good at knowledge production and transfer (Lazaroiu, 2015, p 73). This refer to technological and scientific progress which is important for performance management.

Creativity and knowledge contribute to improve performance. Creativity and knowledge are the most significant economic resource. (Popescu et al, 2016, p.170)

Performance management can improve motivation of employees although they are oriented toward intrinsic motivation. The performance management practices can also succeed in public organizations. The performance related pay (PRP) is considered a good practice to motivate employees to reach higher levels of job performance. Performance is the function of ability (A), motivation to perform (M) and supportive environment $(\mathrm{E})$. [Performance $=\mathrm{f}(\mathrm{A} \mathrm{M} \mathrm{E})$ ].

New Public Management introduced the concept of PRP and this concept has been developed over the past decades by the practitioners as reforms of the public administration. One solution for the public employees to perform better is to replace or supplement the traditional pay system with financial reward for performance or performance related pay (PRP) (OECD, $\mathrm{n} d$ ) 


\section{PEFORMANCE RELATED PAY (PRP) IN FRANCE AND GERMANY}

\subsection{PRP in France}

The pay system of French civil service is basically collective and is applied to 5.5 million people. This information was available at 01/01/2017. French public administration system is a career-based, not position-based, one. The salary for civil servants is called "treatment", it depends on the grade of civil servant and on the function of the "corps" to which he/she belongs. According to 1946 Civil Service Act, one single "grille indiciaire générale" (overall pay scale) applies to all civil servants, with a constant linkage among their basic pay, in accordance with a "republican principle of equal treatment" (Eymeri - Douzans, 2020). In 1957, another salary scale was designed for them, placed on top of the general scale and named it "grille hors-échelle" (an oxymoron meaning "out-of-scale scale"). It does not mention "indices" but only letters, from A to G, whose value in real money remained secret from 1957 to 1982. Top civil servants are the main beneficiaries of the "horséchelle" scale. (Eymeri - Douzans, 2020)

Among all OECD countries, France uses the most career-based recruitment system; performance assessment is frequently used and this process is very important for career advancement and remuneration (OECD, 2012)

The performance-related pay is used to a greater extent than the average OECD countries (OECD, n.d). Performance-related pay is used for most civil servants, it can represent a maximum of 11-20\% of base salary and takes the form of permanent pay increments. In France promotions are also used as a performance incentive.

In conclusion, the performance-related pay can have many benefits for the France public administration and introduce a new culture of performance. Indicators can improve management dialogue.

\subsection{PRP in Germany}

The traditional remuneration system in Germany is determined by federal laws across the 16 lands. German public administration is divided into three categories of public agents, with different conditions of employment: beamte (titular), angestellte - public employees who work under contract, arbeiter - public workers. Baemte represent $30 \%$ and the rest are angestellte and arbeiter. In matters of sovereignty, legislation and promotion of the general interest only beamte can be involved. It is very important to notice that there is not a single HRM authority and this domain is highly decentralised and fragmented. The German Civil Service are marked by traditions andis ruled by a very heavy and complex regulatory framework; there is a lack of explicit and effective HR strategy. One challenge to German Public Administration is to modernize the work program with the hope that it would contribute to a better attractiveness of PA as an employer. One problem is that the system did not include substantial elements of PRP. On the other hand, some authors conclude that PRP was introduced in most entities, but conventional evaluation was predominant and bonuses were distributed equally, without relation to individual performance, and the system, lacking acceptance among employees, had almost no effect on their motivation. (Schmidt et al., 2011).

In conclusion, a proper rewarding strategy, could contribute to attractivity. The main issue is not to increase the performance of the current civil servants but to attract new employees, considering the German demographic decline and the highly legalist institutional framework based on rule of law.

France is a unitary state with a vertical and integrated public administration and Germany is a federal state where there are several layers of civil service and a real autonomy of management of personnel at the territorial level. Romania has an administrative structure similar to that of France. In France PRP is used for most civil servants and takes the forms of permanent pay increments (OECD, 2012) and in Germany PRP is used for the most employees in the form of a bonus. In 
France it can represent $11-20 \%$ of base salary and in Germany it can represent $6-10 \%$ of base salary.

\section{CONCLUSION}

Public workers do value highly the intrinsic reward of work that is important and provides a feeling of accomplishment. The jobs from public administration are recognized as very secure and that is the main reason for which a person wants to work in the public sector. It is necessary to implement methods to stimulate employee motivation and to elaborate and implement consistent strategies regarding career development, work content, working conditions, organizational climate, team spirit and work recognition (Racu, 2019).

Also, it is important to have adequate techniques and tools for financial and non-financial motivation for the public employees. For the managers it is important to recognize the merit of the employees that contribute to the goals and the values of their organizations. Managers using the 360-degree evaluation need to identify and reward those employees who are self-sacrificial in their efforts to accomplish organizational goals.

In addition to theoretical insights into the concept of "motivation" and the basic mechanisms of how this comes about or how it is destroyed, a successful manager also needs an understanding of the way in which structural framework conditions that cannot be directly changed - collective bargaining and legal requirements, demographic developments, financial and socio political trends etc. - affect the motivation of workers.

Performace-related pay (PRP) applied properly in a managerial context can contribute to improving performance. In addition, paying better civil servants allows them to focus only on performing their work duties and this can be a solution to increase their own performance and the organization's performance. To be a real gain for the public institutions, the PRP or other rewards must be distributed also at the middle and lower ranks (not only to the hihger one). On the other hand, the performance rewarding reforms are costly for the public budget.

In France the HR directors recruit the right persons in the right places with 3-year-long contract and they negotiated the salaries, in line with market standards.

In Germany the reforms are aimed to attract young persons to the Civil Service and they hired students as part-time employees.

The results of this article show that the most important intrinsic motivation for the public servants are: job security (in some cases life-employment, guaranteed health insurance, guaranteed pension system), the good compatibility with private life (a good work life balance), more intersting occupation than in the private jobs (more complexity to handle) and the "public service motivation" which according to Perry consists in: commitment to the public interest, compassion for the others, self-sacrifice, attraction to policy-making. (Perry, 1996)

In conclusion, according to Gagné and Deci (2005), intrinsic motivations, compared with the extrinsic dimensions, lead to better levels of individual performance.

\section{ACKNOWLEDGMENT}

This work was supported by a grant of Bucharest University of Economic Studies for institutional projects, project number PI - 2021 - SMFPRUE - 920/16.06.2021, project title “The civil servants' motivation system by comparison between Romania and European Union member states / Sistemul de motivare a funcționarilor publici prin comparație între România și țările membre ale Uniunii Europene" (SMFPRUE). 


\section{REFERENCES}

Brans, M., \& Peters, B. G. (Eds.). (2012). Rewards for high public office in Europe and North America. Routledge.

Ciobanu, A., \& Androniceanu, A. (2015). Civil servants' motivation and work performance in Romanian public institutions. Procedia Econ. Finance J. 30, 164-174. doi: 10.1016/S22125671(15)01280-0

Ciobanu, A., Androniceanu, A., \& Lazaroiu, G. (2019). An integrated psycho-sociological perspective on public employees' motivation and performance. Frontiers in Psychology, 10, 36.

Cameron, J., (2001). Negative Effects of Reward on Intrinsic Motivation - A Limited Phenomenon: Comment on Deci, Koestner, and Ryan, Review of Educational Research, 71(1), 29-42.

European Public Administration Network (EUPAN) (2016). Remuneration and benefits in central government civil service in the EU members states and European Commission, Retrieved November 1, 2021, from www. eupan.eu 2016_2_SK_Remuneration_and_Benefits _in_Central_Government_Civil_Service_in_the_EU_Member_States_and_the_European_Co mmission.pdf

Eymeri-Douzans, J.M (2020). Master course "Management of rewards in the public sector" [Lecture notes].

Forest, V. (2008). Performance-related pay and work motivation: theoretical and empirical perspectives for the French civil service. International review of administrative sciences, 74(2), 325-339.

Gagné, M., \& Deci, E. L. (2005). Self-determination Theory and Work Motivation. Journal of Organizational Behavior, 26(4), 331-62.

Greener, I., (2019). Performance Management That Works? Improving Public Services by Making Use of Intrinsic Motivation. Social Policy \& Administration, 53(1), 99-112.

Hammerschmid, G., Meyer, R. E., \& Egger-Peitler, I. (2009). Das Konzept der Public Service Motivation-Status Quo der internationalen Diskussion und erste empirische Evidenzen für den deutschsprachigen Raum. dms-der moderne staat-Zeitschrift für Public Policy, Recht und Management, 2(1), 13-14.

Hood, C., Peters, B. G., \& Lee, G. (1994). Reward for high public office. London: Sage.

Huston, D. J. (2000). Public-Service Motivation: A Multivariate Test. Journal of Public Administration Research and Theory, 10, 713-728. https://doi.org/10.1093/oxfordjournals. jpart.a024288

Lăzăroiu, G. (2015). The role of the management consultancy industry in the knowledge economy. Psychosociological Issues in Human Resource Management, 3(2), 71-76.

Lăzăroiu, G. (2015). Work motivation and organizational behavior. Contemporary Readings in Law and Social Justice, 7(2), 66-75

Lee, H. W. (2021). Revisiting Crowding-Out Effect of Performance Management: Its Impact on Extrinsic and Intrinsic Motivation. Transylvanian Review of Administrative Sciences, 17(63), 90-109.

McClelland, D. C. (1985). How Motives, Skills, and Values Determine What People Do. American Psychologist, 40 (7), 812-825.

Nickols, F. (2016). Six factors affecting performance alignment. Performance Improvement, 55(3), 6-9.

OECD (n. d). Performance Related Pay for Government Employees, Retrieved November 1, 2021, from https://www.oecd.org/gov/pem/performancerelatedpayforgovernmentemployees.htm.

OECD (2012). Human Resources Management: Country Profiles, Retrieved November 1, 2021, from https://www.oecd.org/gov/pem/hrpractices.htm. 
Perry, J. L., (1996). Measuring public service motivation: An assessment of construct reliability and validity. Journal of public administration research and theory, 6(1), 5-22.

Perry, J. L., Wise, L. R. (1990). The Motivational Bases of Public Service. Public Administration Review, 50, 367-373. https://doi.org/10.2307/976618.

Peters, B. G., (2000). Institutional Theory in Political Science: The New Institutionalism. Continuum.

Piatak, J. S. (2016). Public service motivation, prosocial behaviours, and career ambitions. Int. J. Manpow. 37, 804-821. doi: 10.1108/IJM-12-2014-0248.

Popescu, G. H., Comanescu, M., \& Sabie, O. M. (2016). The role of human capital in the knowledge-networked economy. Psychosociological Issues in Human Resource Management, 4(1), 168.

Pollitt, C., \& Bouckaert, G. (2004). Public management reform: A comparative analysis. Oxford University Press, Retrieved September 30, 2021, from https://www.google.ro/ search?tbm=bks\&hl=en\&q=Pollitt $\% 2 \mathrm{C}+\mathrm{C} . \% 2 \mathrm{C}+\% 26+$ Bouckaert $\% 2 \mathrm{C}+\mathrm{G} .+$

Racu, A. (2019). Motivarea profesională a angajaților autorităților administrației publice locale. Retrieved 1 september, 2021 from http://dspace.aap.gov.md//handle/123456789/1327

Rainey, H.G., \& Steinbauer, P. (1999). Galloping Elephants: Developing Elements of a Theory of Effective Government Organizations. Journal of Public Administration Research and Theory, 9, 1-32. https://doi.org/10.1093/oxfordjournals.jpart.a024401

Riba, C., \& Ballart, X. (2007). La motivación para el servicio público de los altos funcionarios españoles: medida y efectos. Revista Española de Investigaciones Sociológicas, Volume 35, 65-99. https://doi:10.5477/cis/reis.154.65

Ritz, A., Neumann, O., \& Vandenabeele, W. (2016). Motivation in the public sector. Routledge

Schmidt, W., Trittel, N., \& Müller, A. (2011). Performance-related pay in German public services: The example of local authorities in North Rhine-Westphalia. Employee Relations, 33 (2), $140-158$

Selznick, P., (1984). Leadership in Administration: A Sociological Interpretation. Berkeley, University of California Press.

Staats, E., B. (1988). Public Service and the Public Interest. Public Administration Review, 48, 601-605.https://doi.org/10.2307/975760

Steijn, B. (2008). Person-environment Fit and Public Service Motivation. International Public Management Journal, 11(1): 13-27.

Syamsir, S. (2016). The Influence of Public Service Motivation on Service Quality of Civil Servants in West Sumatra Indonesia. European Journal of Economics and Business Studies, 5(1):33. Retrieved September 9, 2021, from https://www.researchgate.net/publication/ 318459344_The_Influence_of_Public_Service_Motivation_on_Service_Quality_of_Civil_Se rvants_in_West_Sumatra_Indonesia/link/5d3829b4299bf1995b4577a9/download.

Vroom, V. H. (1964). Work and Motivation. John Wiley \& Sons.

Wenzel, A. K., Krause, T. A., \& Vogel, D. (2019). Making Performance Pay Work: The Impact of Transparency, Participation, and Fairness on Controlling Perception and Intrinsic Motivation. Review of Public Personnel Administration, 39(2), 232-255.

Wright, B. E., \& Pandey, S. K. (2008). Public Service Motivation and the Assumption of Person Organization Fit: Testing the Mediating Effect of Value Congruence. Administration \& Society, 40 (5), 502-521.

Wright, B. E. (2007). Public service and motivation: do mission matter? Public Administration Review, 67 (1), 54-64. https://doi.org/10.1111/j.1540-6210.2006.00696.x 